\title{
Financial Performance and Corporate Social Responsibility on Return of Shares
}

\author{
Rulyanti Susi Wardhani ${ }^{1}$, Murtiadi Awaluddin' ${ }^{2}$, and Reniati ${ }^{3}$ \\ Faculty of Economics, Bangka Belitung University ${ }^{13}$ \\ UIN Alauddin Makassar Graduate Program ${ }^{2}$ \\ Email: rulyantiwardhani67@gmail.com
}

\begin{abstract}
The purpose of this study is to test the hypothesis of the influence of independent variables namely ROI, ROE, EPS, DER, CSR while the dependent variable is Stock Return. This research approach is a fixed effect approach, general effects, and random effects approach. The sample used in this study was 19 Manufacturing Companies listed on the Indonesia Stock Exchange for the 2015-2018 period. The results showed that ROI, ROE, EPS, and DER partially did not affect Stock Return, while CSR partially affected stock returns on Manufacturing Companies listed on the Indonesia Stock Exchange for the 20152018 period. This means that the companies sampled in this study stated that CSR is a form of commitment in improving welfare through social and environmental responsibility, CSR also provides long-term benefits by increasing the company's reputation and branding, efficiency, internal party appreciation, and strong profitability.
\end{abstract}

Keywords: Financial Performance, Corporate Social Responsibility, Return of Shares.

\section{INTRODUCTION}

Development of economic globalization is advancing the ability of mutual relations lean and also prioritize the competition between countries, not only in international trade but also in investment activities, financial and production (Zaroni, 2015) and it is also supported by the statement. Activities of national economic development in a country's financing is required from government, society and the capital market Capital markets play an important role for the economy of a country due to run two functions: the first function as a medium for trade finance and the latter as a medium for companies to raise capital from investors or investors (Laopodis and Papastamou, 2016). The Capital Market is a platform for trade negotiations of various long-term financial instruments, such as: approvals, equity (mutual funds), mutual funds, derivative instruments and other instruments. Information presented in the Capital Market has an important role in influencing trading transactions in the Capital Market (Fahmi 2014). This information can influence potential investors in making decisions in choosing an efficient investment portfolio from an issuer.

Stock is one of the capital market instruments that many investors in Indonesia. Shares include investments that have a big risk in the long term and has a greater stock return (Pistorius, 2017) return is the main reason people invest (Aisah and Mandala, 2016). A natural thing if investors demand a certain level of return on capital invested. In the context of investment management, there is a return (expected return) and the actual return (Tirrenus return). Return expectations are anticipated level of return investors in the future, while the 
actual return is the rate of return has been obtained by investors in the past (Tjolleng and Manurung, 2013)

The manufacturing company is a company that transforms raw material (the main ingredient) into finished goods through various production processes. Based on data from the Investment Coordinating Board (BKPM) in 2019, the manufacturing sector this year is expected to grow to 5:40 percent, compared to last year grew 4.77 percent (source: www.bkpm.go.id). This condition shows that manufacturing companies provide real contribution to the country's economy Indonesia. A company's performance is a picture of the financial condition of a company that was analyzed using financial analysis, so that can be known about the merits of a company's financial situation which reflects the performance in a particular period (Faisal, Samben, and Pattisahusiwa, 2018. The financial report is a tool in assessing a company in the field of finance. Terhaadap analysis of the company's financial performance can be done by using information from financial data contained in the financial statements (Clementin and Mawar, 2016). Before deciding to invest, investors assess the financial performance that can be done by using financial ratios, so that investors can make investment decisions, whether the shares purchased, sold or retained (Om and Ms, 2017).

Accounting profit, earnings per dividend share, return on investment, return on equity, return on assets, earnings per share, Debt to Equity Ratio, market value-added, economic value-added, current ratio, acid-test ratio, inventory turnover, and the turnover total assets are several kinds of financial ratios (Erica, 2018). The use of financial ratio analysis varies greatly, depending on the need. In general, investor ratios used to determine the return on investment is the return on investment (ROI), return on equity (ROE) and earnings per share (EPS). The main objective of investors investing in the stock market is to obtain a high return, the investor is entitled to know the calculation of the company's financial ratios is published in the financial statements. The financial ratios such as return on investment (ROI), return on equity (ROE), earnings per share (EPS), Debt to Equity Ratio (DER) and measurement of Corporate Social Responsibility (CSR) used by investors to predict stock price sector in the conditions, For investors, CSR is an explanation that a company is not only a benefit but a printer body of interrelated firms in the environmental aspects and social aspects (Auld et al., 2017)

This study draws on research (Jazai et al., 2019) which first examined the ability of Return on Investment (ROI) in affecting stock returns and empirically obtained results that prove ROI can provide a positive influence on stock returns. The previous study that describes the ability of Return on Equity (ROE) in affecting stock returns including research (Saragih, 2018) empirically proved that the ROE can provide a positive influence on stock returns. Earning Per Share (EPS) was not spared of research in influencing stock returns, such research has been done (Jazai et al., 2019), (Atidhira and Yustina, 2017) and (Kai et al., 2018) prove that the EPS can provide a positive influence on stock returns. Unlike the case with research conducted (Maryyam, 2016) empirically prove that EPS is not able to give effect to stock return. As well as Corporate Social Responsibility (CSR), which shows its influence in affecting stock returns are done (Bagaskhara, 2016) empirically prove that CSR is not able to give effect to stock return. Based on the explanation above phenomenon, the authors intend to further examine and test the effect of ROI, ROE, EPS, DER and CSR on stock returns. In this study, researchers tried to test using data years 2015-2018 to reexamine each independent variable. In contrast to previous research, this study adds a 
variable CSR as one of the independent variables with the measurement using dummy variables.

\section{THEORETICAL REVIEW}

Stakeholder theory states that an entity not only operates for its own sake but also to be able to benefit stakeholders in the morning, so the support of stakeholders to entities greatly affect the existence of a company. Support provided stakeholders greatly affect the existence of an entity because stakeholders can control the use of economic resources that are used entities so that the entity trying to find ways to satisfy the desires of stakeholders (Rezaee 2016) suggests that the entity is not only focused on increasing the wealth of the owner or investor, but also must provide services and benefits for corporate stakeholders such as employees, governments, suppliers and the community.

Investation. (Sholihah et al., 2017) investment expressed as a commitment on the amount of capital or other resources is done now, to gain profit in the future.

Stock. Believes that the stock is one of the most popular effects for society. Issuing shares is one option the company when they want to get more funding for the company. According to (Ramalingegowda et al., 2013) shares is evidence of equity participation in a company with a turnover in the company (dividends) distributed to investors, the benefits diiperoleh from the difference between the purchase price and the selling price (capital gain), the benefits of non-financial, among others in the form of power, pride and voting rights in determining the survival company.

Return Stock. (Jogiyanto, 2016) and (Aisah and Mandala, 2016), as well as the stated return is the result obtained from the investment, the return obtained by investors may be capital gains and dividends. According to (Fahmi, 2014) return the profits earned by individuals, companies, or enterprises as a result of its investment policy. A natural thing if investors demand a certain level of return on capital invested. In the context of investment management, there is a return (expected return) and the actual return. Return expectations are anticipated level of return investors in the future, while the actual return is the rate of return has been obtained by investors in the past (Tjolleng and Manurung, 2013)

Return on Investment (ROI). (Shimizu, 2017) Return on Investment as a measure of the ability of the company's overall profit for a total amount of assets available in the company. Fahmi (2014) Return on Investment expressed as the ratio used to see the extent of the investments made capable of delivering returns by the expected and the actual investment equal with invested assets of the company. (Ardiprawiro, 2015) Return on Investment expressed as a ratio showing results (return) on the amount of assets used in the company.

Return on Equity (ROE). (Ardiprawiro, 2015) express Return on Equity (ROE) as a ratio to measure the net profit after tax in their capital. Suggests ROE as a result return on equity or equity by measuring the net profit after tax with their capital. 
Earning Per Share (EPS). (Ardiprawiro, 2015), (Kumar, 2017) defines Earning per Share (EPS) as the ratio to measure management success in achieving keuantungan for shareholders. (Hery, 2015) EPS expressed as a ratio used to measure the success of a management company to provide benefits for the stock. The higher the EPS value, the greater the profit provided to shareholders and the possibility of increasing the number of returns received by shareholders will be increased (Darmadji and Fachrudin 2012).

Debt to Equity Ratio (DER). (Karim and Alam, 2013), and (Alarussi and Alhaderi 2018) defining Debt to Equity Ratio (DER) as the ratio used by companies to measure the ratio between total debt owned company with total assets owned by the company. (Sutrisno, 2013) Debt to Equity Ratio describes as an analysis of the company's financial performance can be done by using information from financial data contained in the financial statements. The higher the ratio DER then the higher the debt financing, making the company difficult to obtain capital loan for fear the company can not use the assets to cover its debts.

Corporate Social Responsibility (CSR).Through disclosure and CSR activities, CSR does not only have strategic value as a form of social investment environment in the long term, CSR is also part of efforts to improve corporate performance, both to maintain business continuity, build a positive image and maintain a good relationship with stakeholders (Bagaskhara., 2016), CSR is based on the idea that the company not only has a dutyeconomic and legal kewajban to shareholders but also to the shareholders that reach beyond those obligations. For investors, CSR is an explanation that a company is not only a benefit but a printer body of interrelated firms in the environmental aspects and social aspects (Atikah et al., 2018).

\section{Framework for Thinking and Hypothesis}

Return on Investment (ROI) to Return Shares. (Fahmi, 2014) ROI expressed as the ratio used to see the extent of the investments made capable of providing returns as expected. Earnings used in measuring this ratio is the net profit after tax. Previous studies conducted by (Jazai et al., 2019) we concluded that the ROI has a significant and positive influence on stock returns. The level of good corporate ROI certainly attract investors to own shares of the company, due to the high ROI increasing return. If investors to buy shares of the company increases, the company's stock price also increased, followed by a large stock returns. Based on the above, it can be presumed that ROI has a positive effect on stock returns and the theoretical basis of the above result in the following hypotheses:

Ha1: Return on Investment (ROI) partially significant and positive impact on stock returns.

Return on Equity (ROE) and Return Shares. Return on Equity expressed as a result return on equity or equity by measuring the net profit after tax with their capital. The more efficient use of equity for a profit, then the return obtained by investors will be high (Bagaskhara 2016). This means that the higher the ROE, the higher the return received by investors. Previous studies conducted by (Saragih, 2018), we concluded that the ROE has a positive and significant impact on stock returns. Good corporate ROE level certainly attract investors to own shares of the company, because of the high ROE indicates the higher the return received by investors. 
Ha2: Return on Equity (ROE) partially significant and positive impact on stock returns.

Earning per Share (EPS) and Stock Return. According to (Ardiprawiro, 2015) that the Earning per Share (EPS) as the ratio to measure management success in achieving keuantungan for shareholders. The higher the EPS value, the greater the profit provided to shareholders and the possibility of increasing the number of returns received by shareholders increased. Thus the higher the income provided by the company, the higher the returns received by investors. Previous studies conducted by (Jazai et al., 2019); (Atidhira and Yustina, 2017) EPS is concluded that significant and positive impact on stock returns. EPS information showing the extent of a company's net profit entities are distributed to all shareholders. EPS shows the share of profits of any shares received by shareholders then to determine earnings per share, the shareholders can decide to invest.

Ha3: Earning per Share (EPS) partially significant and positive impact on stock returns.

Debt to Equity Ratio (DER) and Stock Return. (Anuar and Chin, 2016) defining Debt to Equity Ratio (DER) as the ratio used by companies to measure the ratio between total debt owned company with total assets owned by the company. The higher the ratio DER then the higher the debt financing, making the company difficult to obtain capital loan for fear the company can not use the assets to cover its debts. (Bagaskhara, 2016) DER states became one of the ratios that can be used investors to analyze the use of long-term debt. Thus the higher DER affect a company. Previous studies conducted by (Bagaskhara, 2016); and (Atidhira and Yustina, 2017) we concluded that the DER has a significant and positive influence on stock returns.

Ha4: Debt to Equity Ratio (DER) partially significant and positive impact on stock returns.

Corporate Social Responsibility (CSR) and Stock Return. Aigner (2016) defines Corporate Social Responsibility (CSR) as the company's commitment to improve the welfare of the community through good business activity and use part of the company's resources. For investors, CSR is an explanation that a company is not only a benefit but a printer body of interrelated firms in the environmental aspects and social aspects (Auld et al., 2017).

Ha5: Corporate Social Responsibility (CSR) partially significant and positive impact on stock returns.

Relationships of all variables in this study can be shown in the Figure below: 
Figure 1. Framework for Thinking

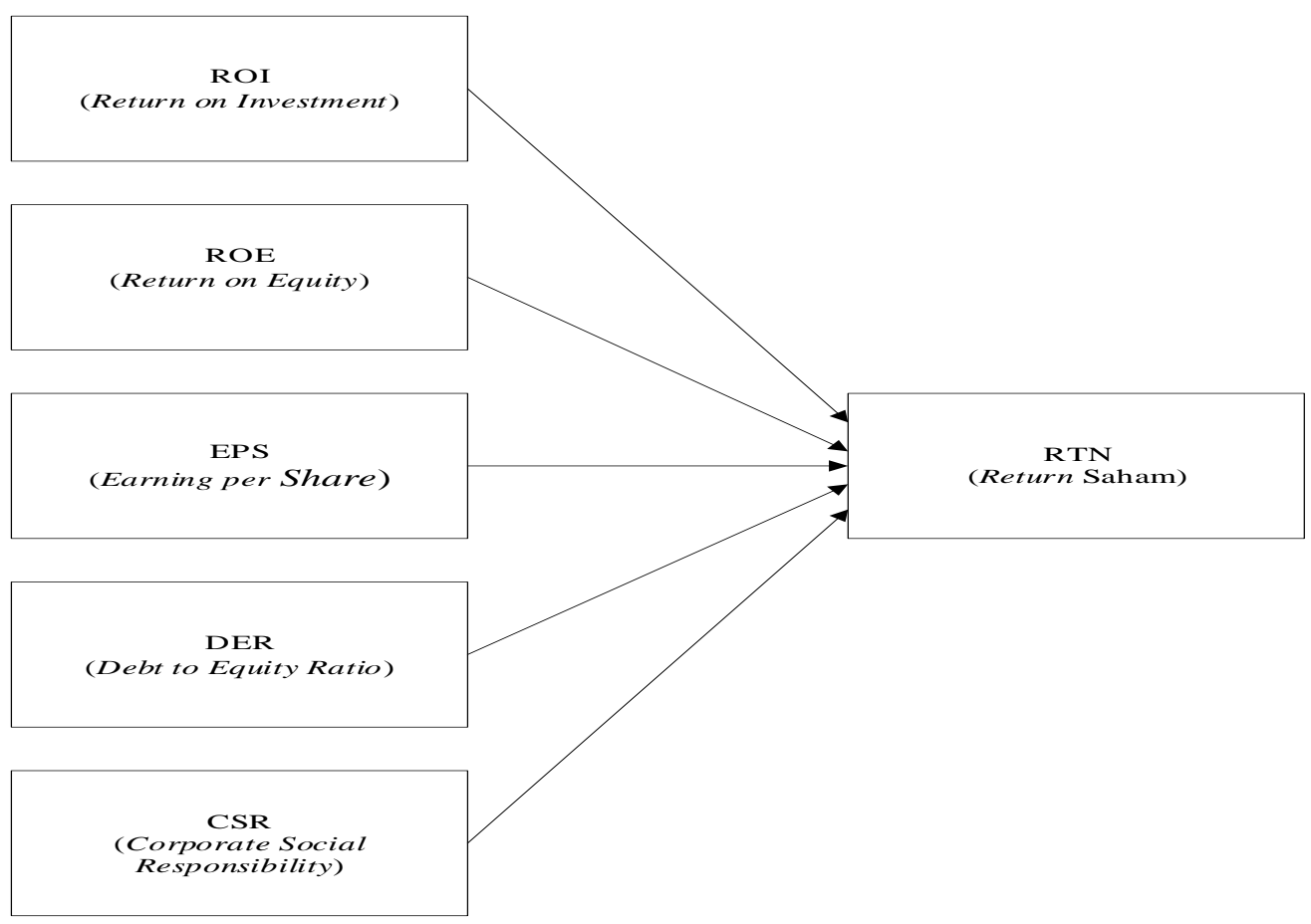

\section{METHODOLOGY}

Research design. This research is an explanatory research (Lee and Cronin, 2016) to test hipotesispengaruh one or several variables (independent) on another variable (the dependent variable). The independent variables used were ROI, ROE, EPS, DER, while CSR for the dependent variable is the Stock Return.

Research Subjects. The research subject or population Manufacturing companies listed in Indonesia Stock Exchange (BEI) in the period from 2015 to 2018 as many as 156 companies. Taking sampling method is purposive sampling using (Bhattacherjee, 2012). By determining the number of samples is based on a balance and specific objectives of researchers. The consideration used in selecting the samples in the study were as follows: 1) Manufacturing Companies listed on the Indonesia Stock Exchange (BEI) in the period 2015-2018. 2) Manufacturing Companies who publish and publish the audited financial statements for the fiscal year 2015-2018 in full and has a positive income and 3) Manufacturing Company which has the publication of data associated with stock return, ROI, ROE, EPS, DER and CSR. After balancing on these criteria, it is obtained as many as 19 companies which can be used as a sample. The data obtained in the study through the official website of Indonesia Stock Exchange (www.idx.co.id) Shares OK (www.sahamok.com, Data from the world of investments (www.duniainvestasi.com), As well as Yahoo Finance (www.finance.yahoo.com). 
Research Process Flow.This study categorized explanatory research that explain the causal relationship between variables hypothesis testing. The process of this study are summarized in the flowchart in the form of a fishbone, as follows:

Figure 2. Flowchart

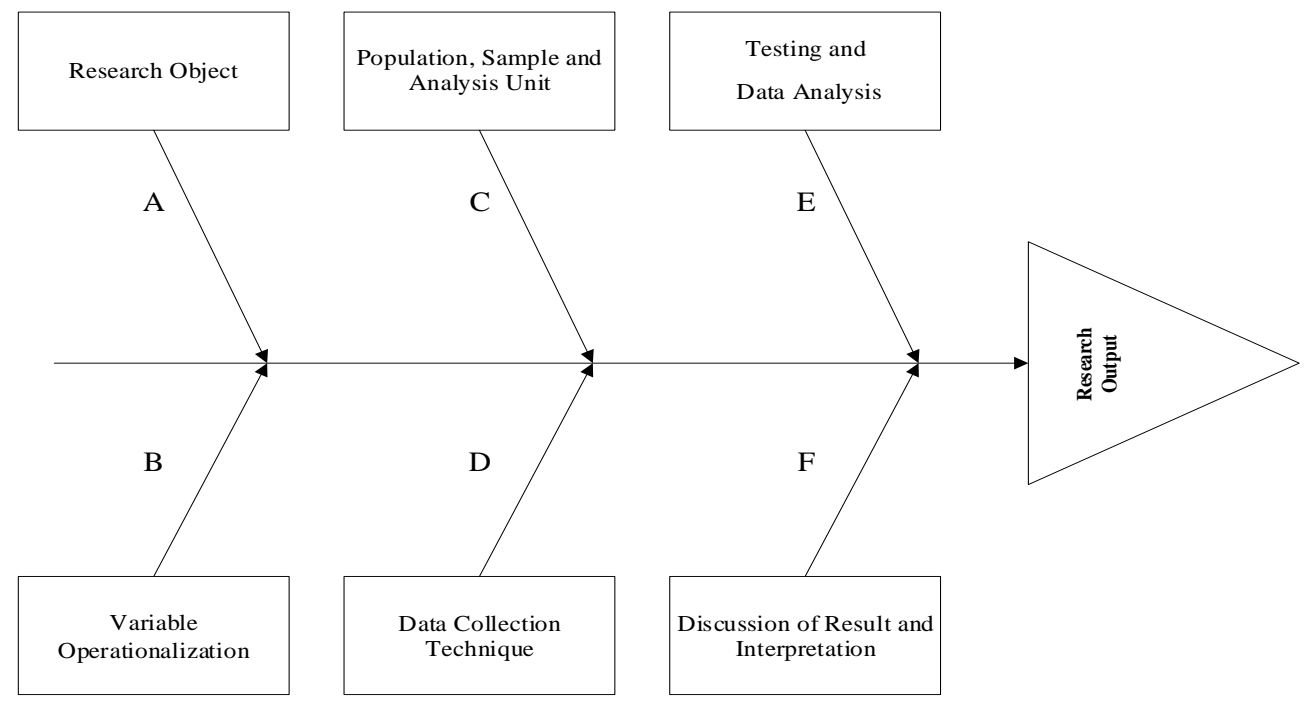

\section{Definition of Variable Operations}

Operations in this study are described in Table 2 below:

Table 2. Operationalization of Variables

\begin{tabular}{cc}
\hline variables & Formula \\
\hline ROI & ROI $=\frac{\text { Net Profit After Tax }}{\text { Total Assets }}$ \\
\hline ROE $=\frac{\text { Net Profit After Tax }}{\text { Total Equity }}$ \\
\hline EPS & EPS $=\frac{\text { Net Profit After Tax }}{\text { Number of } \text { shares outstanding }}$ \\
\hline DER & DER $=\frac{\text { Total Debt }}{\text { Total Capital }}$ \\
CSR & CSRit $=\frac{\sum x \text { it }}{\mathrm{ni}}$
\end{tabular}

Source: (Processed Data, 2020)

Analysis Method. Data were tested in the form of panel data is analyzed multiple regression premises. The stages as follows: 1) Analysis Descriptive statistics, 2) Classical Assumption Test includes test: Normality, Multicollinearity, Heteroskidastity, and autocorrelation, 3) Test the hypothesis meluputi coefficient of determination $\left(\mathrm{R}^{2}\right)$ and F-test and t-test statistics. 


\section{THE RESULTS OF STATISTICAL TESTS}

Description Analysis. Describing the description of the data seen from the mean, maximum, minimum, and standard deviation of each variable, Calculation of the independent variables and the dependent variable in show in Table 3.

Table 3. Test Result of Descriptive Statistics

\begin{tabular}{lllllll}
\hline & N & Minimum & Maximum & mean & median & Std. deviation \\
& & & & & & \\
\hline ROI & 76 & 0.0002 & .921 & .1338 & .0783 & .1528 \\
ROE & 76 & -0.0248 & 2.2446 & 0.301 & .1431 & .4342 \\
EPS & 76 & 0.0001 & 2707.929 & 333.039 & 109.324 & 501.665 \\
CSR & 76 & .0659 & .2637 & .1524 & 0.1429 & .0472 \\
DER & 76 & -6.9299 & 94.0997 & 2.0511 & .4325 & 10.985 \\
Stock returns & 76 & -0.8953 & 2.7255 & .1635 & .0405 & 0.578 \\
& & & & & & \\
\hline
\end{tabular}

Source: processed data, 2019

Number of samples (N). The number of samples contained 76 Manufacturing Companies listed on the Stock Exchange for 4 years in a row consisting of: ROI, ROE, EPS, CSR, DER and Stock Returns.

Return on Investment. ROI for Enterprise Manufacturing has fluctuated from year to year with the lowest value of 0.0002 on PT Voksel Electric Tbk (VOKS) in 2015. This condition is due to the lower net income so as to make the ROI from enterprise VOKS the lowest compared to other manufacturing companies. Furthermore, the value of the highest ROI in the company PT Brands Indonesia Tbk (MERK) in 2018, the cause of this company experienced an increase in net income is greater than the increase in total assets of the company. While the average value ROI manufacturing enterprises amounted to 0.1338 , the median of 0.0783 and a standard deviation of 0.1528 . Increased or decreased the ROI on manufacturing companies in Indonesia Stock Exchange for the years 2015-2018 can be described in the following graph:

Figure 3. Graph ROI manufacturing companies in BEI period 2015-2018

Source: processed data, 2019

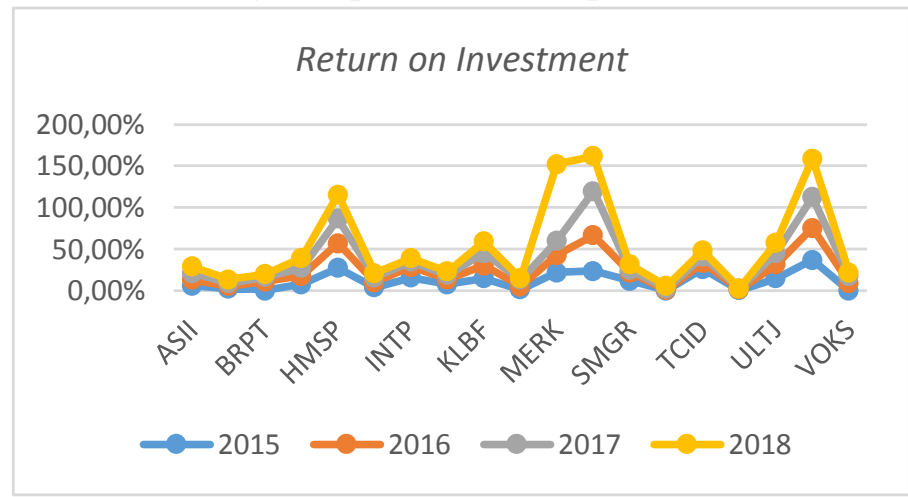


Based on Figure 3 above shows that the ROI has fluctuated from year to year due to the increase in net income is not significant and followed the increase or decrease in the company's assets. This is because all the years of research, purchasing power stagnant amid inflation tends to be low. Low inflation is accompanied by a decrease in purchasing power resulted in the company's competitiveness also lost. The occurrence of de-industrialization, faster cause a decrease in the portion of manufacturing to GDP of Indonesia, it is also exacerbated by the changing patterns of foreign investment that tends to be in the tertiary sector (services, economic, or digital) than the secondary sector (manufacturing) (Source: Institute for Development of Economics and Finance).

Return on Equity. ROE value of the companies listed on the Stock Exchange 2015-2018 period based on Table 3 explains that fluctuated from year to year with the lowest value 0.0248 PT Sumalindo Lestari Jaya Tbk (SULI) in 2016, this was due to the increase in net income in 2016 amounted to $23.84 \%$ and decreased equity $(-28.54 \%)$. The highest ROE value of 2.2446 by PT Merck Indonesia (BRANDS) in 2018 due to higher revenue generated in 2018 is greater than the increase in total equity of the company. While the average value of a manufacturing company's ROE is equal to 0.301 , the median of 0.1431 and a standard deviation of 0.4342 .

Figure 4. ROE Graph manufacturing companies in BEI period 2015-2018

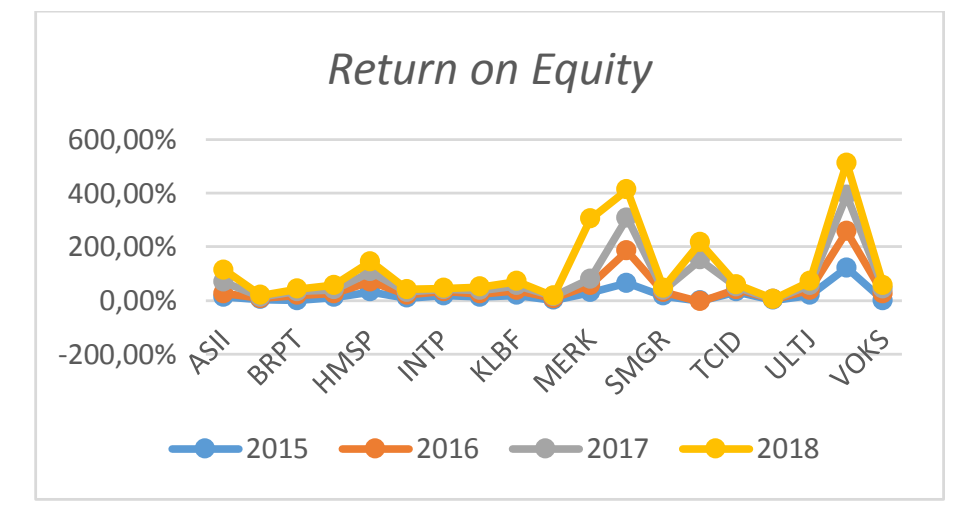

Source: (BEI, 2019)

Figure 4 above illustrates that the ROE has fluctuated from year to year due to the increase in net income is not significant and accompanied by an increase or decrease in the company's equity. This is because all the years of research, the tax ratio Indonesia recorded a declining trend which led to the achievement of the tax ratio is still far from the target. Meanwhile, the increase in the debt-to-GDP ratio is inversely proportional to the tax ratio, the implication burden of higher debt interest payments. Another thing that causes fluctuations in the company's profit is the discourse of the Industrial Revolution 4.0 is not done with careful planning (Source: Institute for Development of Economics and Finance).

Earnings per Share, EPS companies listed on the Stock Exchange from the 2015-2018 year has fluctuated from year to year with the lowest value of Rp 0.0001, - by PT Sumalindo Lestari Jaya Tbk (SULI) in 2015. The highest EPS value of Rp 2707.93, - PT Mandom Indonesia Tbk (TCID) in 2015. While the average value of Rp 333.04, - a median of Rp 
109.32 and a standard deviation of USD 501665 . Increased or decreased the EPS on manufacturing companies in Indonesia Stock Exchange for the years 2015-2018 can be described in the following graph:

Figure 5. Graph EPS manufacturing companies in BEI period 2015-2018

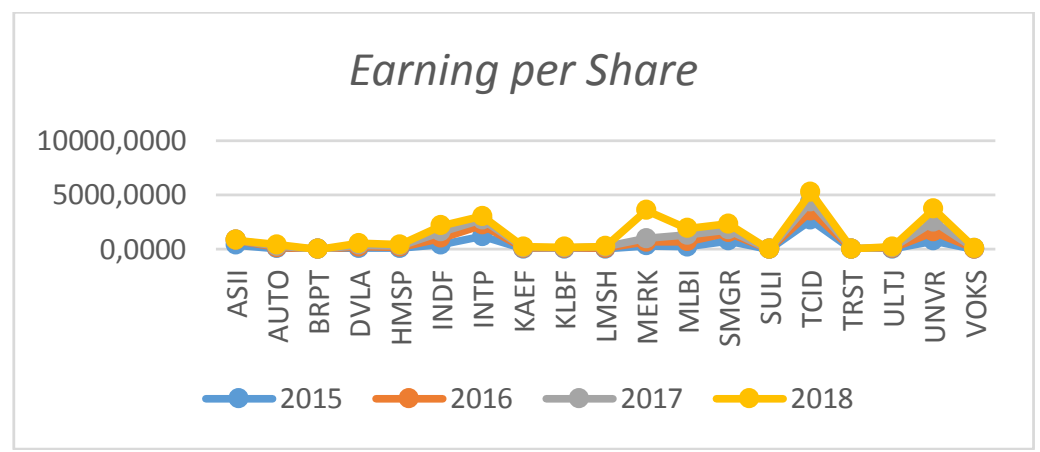

Source: (BEI, 2019)

Earnings per Share has fluctuated from year to year due to the rise in its net profit and is accompanied by the number of shares outstanding. This is because of all the years of research, there are several listed companies on the Stock Exchange which make a profit per share is quite high. EPS each issuer equalization level is different and followed by return throughout the year different. BEI recorded a profit of companies listed on the stock market grew $0.15 \%$ despite the turmoil outside (global) but assets showed a positive position. Changes in earnings per share can occur because of the company's initial public offering (Initial Public Offering), Real Estate Investment Trusts (DIRE), Exchange Trade Fund (ETF), and the Infrastructure Investment Fund (Dinfra) (Source: www.katadata. co.id).

Debt to Equity Ratio. DER value of companies listed on the Stock Exchange from the 2015-2018 year has fluctuated from year to year with the lowest value of -6.9299 PT Sumalindo Lestari Jaya Tbk (SULI) in 2016, this was due to a decline in the company's capital and debt, DER value high of 94.0997 by PT Sumalindo Lestari Jaya Tbk (SULI) in 2017 this was due to increased borrowing by the company. While the average value of 2.0511 , the median of 0.4325 and a standard deviation of 10.985. Increased or decreased the DER onmanufacturing companies in Indonesia Stock Exchange for the years 2015-2018 can be described in the following graph:

Figure 6. Graph DER manufacturing companies in BEI period 2015-2018

Source: (BEI, 2019)

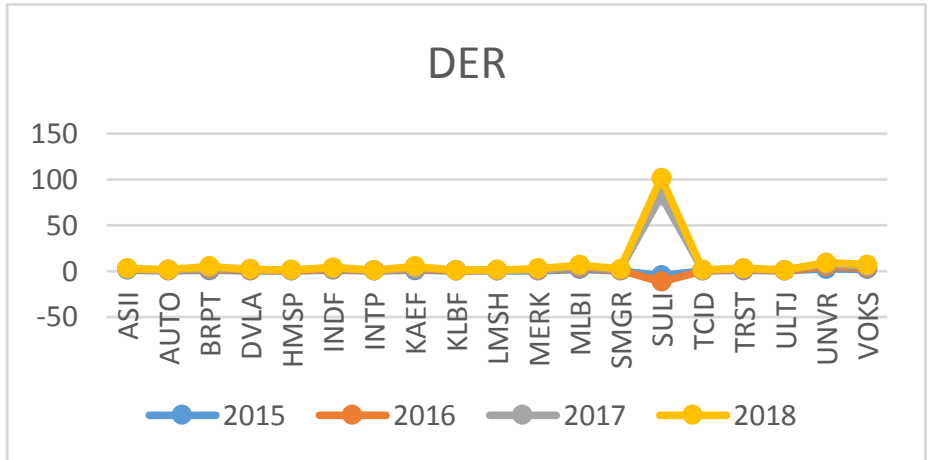


Showed that the DER on manufacturing companies in the BEI period 2015-2018 fluctuated from year to year due to the increase/decrease of capital and debt, as well as increased borrowing. This is due to large debts usually followed with considerable interest costs. Debt in foreign currency is quite worrying because if this happens then the depreciation of the rupiah debt financing could grow twofold. Investors also need to consider net income and operating cash flow.

Corporate Social Responsibility.CSR value of companies listed on the Stock Exchange from the 2015-2018 year has fluctuated from year to year with the lowest value of 0.0659 by PT Lion Mess Prima Tbk (LMSH) in 2015 and this is because of at least the disclosure of CSR activities undertaken by the company the. The highest CSR value of 0.2637 by PT Astra International Tbk (ASII) in 2015 and this is because of many disclosures of CSR activities undertaken by the company. While the average value of 0.1524 , the median of 0.1429 and a standard deviation of 0.0472. Increased or decreased the CSR on manufacturing companies in Indonesia Stock Exchange for the years 2015-2018 can be described in the following graph:

Figure 7. CSR Graph manufacturing companies in BEI period 2015-2018

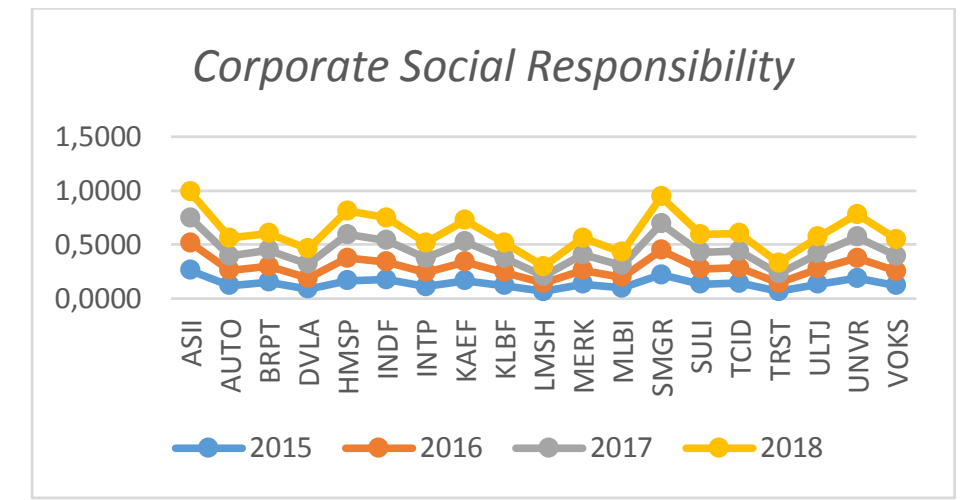

Source: processed data, 2019

Stock returns. Return Value Manufacturing Company shares listed on the Stock Exchange from the year 2015-2018 fluctuated with the lowest value of - 0.8953 at PT Lion Mess Prima Tbk (LMSH). In 2015, it happened decline in the company's stock price is Rp 5,875 wherein 2014 the company's stock price is Rp 6,450, - fell to USD 575 in 2015. The highest value of 2.7255 by PT Sumalindo Lestari Jaya Tbk (SULI) 2016 previously in 2015 amounted to Rp 51, - rose to Rp 190, - in 2016. Meanwhile, the average value of 0.1635 , the median of 0.0405 , and a standard deviation of 0.578. Return the stock has fluctuated from year to year due to changes in price and performance of the Composite Stock Price Index (CSPI) is a company that is not stable. This is because of all the years of research, unstable stock prices of companies in the capital market. JCI 2016 returns of $19.99 \%$ and in 2017 fell to $15.32 \%$. JCI in 2018 spelled out the worst in the last 3 years after minus $2.54 \%$ in a year, but the decline in the index in 2018 was better than 2015 which is minus $12.13 \%$. The decline in the index over the past year can not be released from several negative catalyst either from within the city, such as economic growth, depreciation of the exchange rate, trade deficit, up sentiment abroad (Source: CNBC Indonesia). 
The following chart Stock Return fluctuations in manufacturing companies listed on the Stock Exchange 2015-2018 period: $99 \%$ and in 2017 fell to $15.32 \%$. JCI in 2018 spelled out the worst in the last 3 years after minus $2.54 \%$ in a year, but the decline in the index in 2018 was better than 2015 which is minus $12.13 \%$. The decline in the index over the past year can not be released from several negative catalyst either from within the city, such as economic growth, depreciation of the exchange rate, trade deficit, up sentiment abroad (Source: CNBC Indonesia). The following chart Stock Return fluctuations in manufacturing companies listed on the Stock Exchange 2015-2018 period: $99 \%$ and in 2017 fell to $15.32 \%$. JCI in 2018 spelled out the worst in the last 3 years after minus $2.54 \%$ in a year, but the decline in the index in 2018 was better than 2015 which is minus $12.13 \%$. The decline in the index over the past year can not be released from several negative catalyst either from within the city, such as economic growth, depreciation of the exchange rate, trade deficit, up sentiment abroad (Source: CNBC Indonesia).

The following chart Stock Return fluctuations in manufacturing companies listed on the Stock Exchange 2015-2018 period: The decline in the index over the past year can not be released from several negative catalyst either from within the city, such as economic growth, depreciation of the exchange rate, trade deficit, up sentiment abroad (Source: CNBC Indonesia). The following chart Stock Return fluctuations in manufacturing companies listed on the Stock Exchange 2015-2018 period: The decline in the index over the past year can not be released from several negative catalyst either from within the city, such as economic growth, depreciation of the exchange rate, trade deficit, up sentiment abroad (Source: CNBC Indonesia). The following chart Stock Return fluctuations in manufacturing companies listed on the Stock Exchange 2015-2018 period:

Figure 8. Graph Stock Return manufacturing companies in BEI period 2015-2018

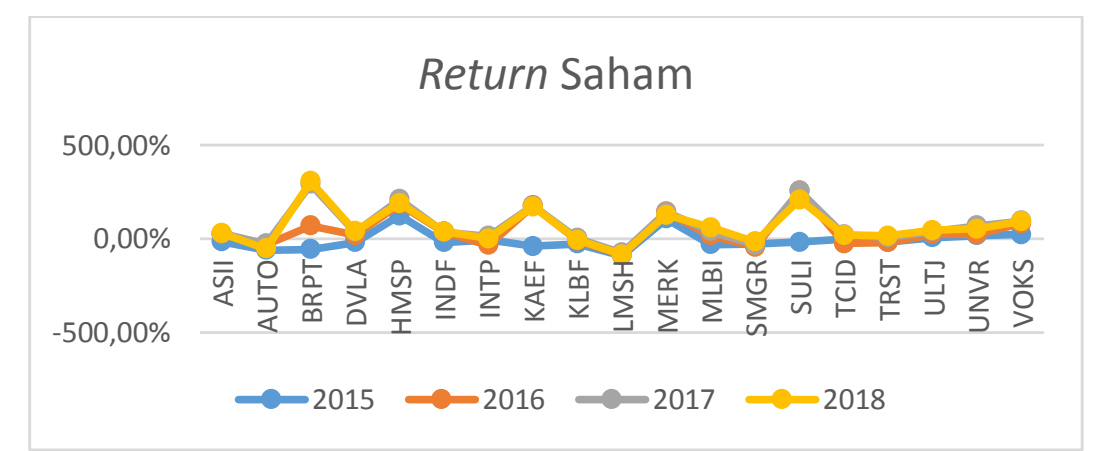

Source: (Data processed, 2019)

Panel Data Regression Model Estimation. When put through multiple linear regression analysis using the panel data can not be separated by three approaches namely common effect, fixed effect and random effect. Furthermore, the results of these three approaches are: 


\section{Effect Common Approach.}

Table 4. The model common effect is illustrated in

\begin{tabular}{|c|c|c|c|c|}
\hline variable & coefficient & Std. Error & t-Statistic & Prob. \\
\hline$C$ & -1.483731 & 0.734094 & -2.021174 & 0.0505 \\
\hline$R O I$ & 5.240161 & 3.403574 & 1.539606 & 0.1322 \\
\hline$R O E$ & -1.647125 & 1.295654 & -1.271270 & 0.2116 \\
\hline EPS & 0.000722 & 0.000928 & 0.777315 & 0.4419 \\
\hline$D E R$ & -0.193248 & 0.162004 & -1.192859 & 0.2405 \\
\hline$C S R$ & -2.369342 & 4.351267 & -0.544518 & 0.5894 \\
\hline$R$-squared & \multicolumn{3}{|c|}{0.125589 Mean dependent var } & -1.549828 \\
\hline Adjusted $R$-squared & \multicolumn{3}{|c|}{$0.007425 S D$ dependent var } & 1.273827 \\
\hline SE of regression & \multicolumn{3}{|c|}{ 1.269089Akaike information criterion } & 3.443264 \\
\hline Sum squared resid & \multicolumn{3}{|c|}{ 59.59175Schwarz criterion } & 3.689013 \\
\hline Log likelihood & \multicolumn{3}{|c|}{-68.03017 Hannan-Quinn criter. } & 3.533888 \\
\hline$F$-statistic & \multicolumn{3}{|c|}{ 1.062838Durbin-Watson stat } & 1.064399 \\
\hline Prob (F-statistic) & \multicolumn{3}{|c|}{0.396482} & \\
\hline
\end{tabular}

Source: (Data processed, 2019)

Table 5. Fixed Effect Approach

\begin{tabular}{ccccr}
\hline variable & coefficient & Std. Error & t-Statistic & Prob. \\
\hline \hline C & 2.599970 & 2.646629 & 0.982370 & 0.3383 \\
ROI & 4.740910 & 16.29247 & 0.290988 & 0.7742 \\
ROE & -0.765701 & 4.703834 & -0.162782 & 0.8724 \\
EPS & 0.006348 & 0.003704 & 1.713865 & 0.1028 \\
DER & 0.413936 & 1.521674 & 0.272026 & 0.7885 \\
CSR & -41.55950 & 13.42707 & -3.095203 & 0.0060 \\
\hline \hline
\end{tabular}

Cross-section fixed (dummy variables)

$\begin{array}{lccr}R \text {-squared } & 0.767944 & \text { Mean dependent var } & -1.549828 \\ \text { Adjusted } R \text {-squared } & 0.487035 & \text { SD dependent var } & 1.273827 \\ \text { SE of regression } & 0.912336 & \text { Akaike information criterion } & 2.953900 \\ \text { Sum squared resid } & 15.81477 & \text { Schwarz criterion } & 3.936896\end{array}$


Log likelihood

$-39.50885$

F-statistic

Prob (F-statistic)

Source: Data processed, 2019.

After getting the common effect and fixed effect chow then the next test. The testing is required to select the most appropriate model among the models common effect and fixed effect models. Chow test results can be seen in Table 6 .

Table 6. Test Results Chow

\begin{tabular}{lccc}
\hline \multicolumn{1}{c}{ Effects Test } & statistics & df & Prob. \\
\hline \hline Cross-section F & 2.921892 & $(18,19)$ & 0.0126 \\
Cross-section Chi-square & 57.042640 & 18 & 0.0000 \\
\hline \hline
\end{tabular}

Source: (Data processed, 2019)

Table 7. Random Effect Approach

\begin{tabular}{|c|c|c|c|c|}
\hline variable & coefficient & Std. Error & t-Statistic & Prob. \\
\hline$C$ & -1.036779 & 0.867109 & -1.195672 & 0.2394 \\
\hline$R O I$ & 5.962654 & 4.105033 & 1.452523 & 0.1548 \\
\hline$R O E$ & -2.213810 & 1.465956 & -1.510148 & 0.1395 \\
\hline$E P S$ & 0.001431 & 0.000975 & 1.468418 & 0.1504 \\
\hline$D E R$ & -0.243614 & 0.165545 & -1.471585 & 0.1496 \\
\hline$C S R$ & -5.464805 & 5.259237 & -1.039087 & 0.3055 \\
\hline \multicolumn{5}{|c|}{ Effects Specification } \\
\hline & & & $S D$ & Rho \\
\hline Cross-section random & & & 0.867333 & 0.4747 \\
\hline idiosyncratic random & & & 0.912336 & 0.5253 \\
\hline \multicolumn{5}{|c|}{ weighted Statistics } \\
\hline$R$-squared & 0.151714 & \multirow{5}{*}{\multicolumn{2}{|c|}{$\begin{array}{l}\text { Mean dependent var } \\
\text { SD dependent var } \\
\text { Sum squared resid } \\
\text { Durbin-Watson stat }\end{array}$}} & -0.841070 \\
\hline Adjusted R-squared & 0.037081 & & & 0.998016 \\
\hline SE of regression & 0.999132 & & & 36.93577 \\
\hline$F$-statistic & 1.323472 & & & 1.646146 \\
\hline \multirow[t]{2}{*}{$\operatorname{Prob}(F$-statistic $)$} & 0.275637 & & & \\
\hline & \multicolumn{3}{|c|}{ unweighted Statistics } & \\
\hline$R$-squared & 0.097212 & \multirow{2}{*}{\multicolumn{2}{|c|}{$\begin{array}{l}\text { Mean dependent var } \\
\text { Durbin-Watson stat }\end{array}$}} & -1.549828 \\
\hline Sum squared resid & 61.52562 & & & 0.988234 \\
\hline
\end{tabular}

Source: (Data processed, 2019) 
In the preceding table that uses a fixed effect and the table above using random effects models. Determine which model is more appropriate it is necessary Hausman test to find out. Hausman test results are shown in Table 8

Table 8. Test Results Hausman

\begin{tabular}{lccr} 
Test Summary & Chi-Sq. statistics & Chi-Sq.df & Prob. \\
\hline \hline & & & \\
Cross-section random & 11.726566 & 5 & 0.0387 \\
\hline \hline
\end{tabular}

Based on Hausman test results above, it can be seen from the cross section of random probability value which is equal to 0.0387 the value is less than 0.05 means that $\mathrm{HO}$ is rejected, so that the model chosen is the Fixed Effects Model.

Classic Assumption Test.This study uses a panel regression model, the test results was fixed effect model selection model so no need to test the classical assumption (Surjandari et al. 2019).

\section{Hypothesis Test}

Coefficient of Determination. The coefficient of determination used to measure how far the model's ability to explain the variations dependent. Adjusted R-square value approaching one means the ability of independent variables provides almost all the information needed to predict the variation pliers dependent. The coefficient of determination can be seen in Table. 9 following:

Table 9. Table Test Coefficient of Determination

\begin{tabular}{lccr}
\hline \multicolumn{3}{c}{ Cross-section fixed (dummy variables) } \\
\hline \hline R-squared & 0.767944 & Mean dependent var & -1.549828 \\
Adjusted $R$-squared & 0.487035 & SD dependent var & 1.273827 \\
SE of regression & 0.912336 & Akaike information criterion & 2.953900 \\
Sum squared resid & 15.81477 & Schwarz criterion & 3.936896 \\
Log likelihood & -39.50885 & Hannan-Quinn criter. & 3.316398 \\
F-statistic & 2.733777 & Durbin-Watson stat & 3.823552 \\
Prob $($ F-statistic) & 0.014800 & & \\
\hline \hline
\end{tabular}

Source: (Data processed, 2019)

Based on Table 9 of the figures adjusted R-square (R2) is 0.487035 . This shows that the percentage contribution of the influence of the independent variable on the dependent variable is equal to $48.70 \%$ or it can be interpreted that the independent variables used in the model can explain amounted to $48.70 \%$ of the dependent variable. The remaining $51.30 \%$ are influenced by other factors outside the regression model.

F-Test (Simultaneous). Effect of Variable ROI, ROE, EPS, and CSR to the Stock Return partially used $F$. Test $F$ test is used to determine whether independent variables jointly affect 
the dependent variable or to determine whether the regression model can be used to predict the dependent variable or not, If the value of $\mathrm{F}$ count $>\mathrm{F}$ table then $\mathrm{H} 0$ is rejected and it can be concluded that the simultaneous independent variables affect the dependent variable. If the value of $\mathrm{F}<\mathrm{F}$ table then $\mathrm{H} 0$ is accepted and can be concluded that there are no independent variables that affect the dependent variable.

Simultaneous hypothesis test using the F test can be seen in Table 10 below:

Table 10. F Test

\begin{tabular}{lcr}
\hline \hline & Cross-section fixed (dummy variables) & \\
\hline \hline R-squared & 0.767944 Mean dependent var & -1.549828 \\
Adjusted $R$-squared & 0.487035 SD dependent var & 1.273827 \\
SE of regression & 0.912336 Akaike information criterion & 2.953900 \\
Sum squared resid & 15.81477 Schwarz criterion & 3.936896 \\
Log likelihood & -39.50885 Hannan-Quinn criter. & 3.316398 \\
F-statistic & 2.733777 Durbin-Watson stat & 3.823552 \\
Prob $($ F-statistic) & 0.014800 & \\
\hline \hline
\end{tabular}

Source: (processed data, 2019)

By hypothesis:

$\mathrm{H}_{0}=$ No significant effect between the variables of ROI, ROE, EPS, and CSR simultaneously to return stock

$\mathrm{H}_{1}=$ There is a significant influence between the variables of ROI, ROE, EPS, and CSR simultaneously to return stock

Based on the output results Eviews above, the value of $\mathrm{F}$ is equal to 2.733777 while the $\mathrm{F}$ table with level $=5 \%$ is of 2.35 . Thus $\mathrm{F}$ count $>\mathrm{F}$ table $(2.733777>2.35)$ then also visible from a probability value that is equal to 0.014800 smaller than the significance level of $0.05(0.014800<0.05)$ so H0rejected. This indicates that the variable ROI, ROE, EPS, and CSR together (simultaneously) has a significant influence on stock returns, so the regression model can be used to predict the dependent variable.

The T-test (partial).Effect of Variable ROI, ROE, EPS, and CSR to Stock Return by partial ie using statistical t-test. See the influence of variables using a partial test or t-test is used to test each independent variable on the dependent variable. Partial hypothesis test using t-test can be shown in Table 11 below: 
Table. 11 Uji t-statistic

\begin{tabular}{crrrr}
\hline \hline variable & coefficient & Std. Error & t-Statistic & Prob. \\
\hline \hline C & 2.599970 & 2.646629 & 0.982370 & 0.3383 \\
ROI & 4.740910 & 16.29247 & 0.290988 & 0.7742 \\
ROE & -0.765701 & 4.703834 & -0.162782 & 0.8724 \\
EPS & 0.006348 & 0.003704 & 1.713865 & 0.1028 \\
DER & 0.413936 & 1.521674 & 0.272026 & 0.7885 \\
CSR & -41.55950 & 13.42707 & -3.095203 & 0.0060 \\
\hline \hline
\end{tabular}

Source: processed data, 2019

According to the table above, the partial correlation of each variable on stock returns is as follows:

Influence ROI on Stock Return. The test results show the panel data regression analysis of the results of t-test for independent variables ROI is equal to 0.290988 while the value of the t-table with $\propto=5 \%$ and $\mathrm{df}=(\mathrm{nk}), \mathrm{df}=(76-5)=71$ where $\mathrm{t}$-table is equal to 1.66691 , which means that the value $t$ count is smaller than $t$-table $(0.290988<1.66691)$, and when viewed from the probability is equal to 0.7742 which is greater than $0.05(0.7742>0.05)$ $\mathrm{HO}$ is accepted. This means that the return on investment has no significant effect.

The results of this study are not by the stakeholder theory states that the company must provide benefits to stakeholders. One measure of financial profitability ratios to determine the ROI of corporate profits is, the higher the level of profit generated then raise the company's stock price. However, when the company gets additional profit, the company tends to act to maximize the benefit of the company (private interests) so that the welfare of shareholders less than the maximum. The rate of return earned is not affected by the high ROI that is caused by the internal transfer of profits for the sake of the company.

These results are consistent with the results of previous studies found that ROI has no significant effect on stock returns, which means increasing the ROI is not necessarily impact to rising stock returns obtained by investors conducted by (Sari et al., 2017). This study is not in line with the (Jazai et al., 2019) which states that the ROI affects stock returns.

ROE influence on Stock Return. The test results show the panel data regression analysis of the results of t-test for independent variables ROE is equal to -0.162782 while t-table value is equal to 1.66691 , which means that the t-count value is smaller than t-table ($0.162782<1.66691)$, and when viewed from the probability is equal to 0.8724 which is greater than $0.05(0.8724>0.05) \mathrm{H} 0$ is accepted. This means that the Return on Equity has no significant effect on stock returns.

The results of this study are not by the stakeholder theory states that the company must provide benefits to stakeholders. ROE is a financial measuring tool to calculate how big the company's profit on own capital that has been managed by the company. The high ROE will increase because stock returns ROE describes the company generated profit. However, the additional profits from the company are used for long-term business expansion, so the returns provided are not allocated to shareholders. Companies tend to be concerned with their own interests by using the return for the continuation of the business so that the welfare of shareholders less preferred. 
These results are consistent with results of previous studies found that the ROE does not have a significant effect on stock returns, which means increasing the value of ROE does not necessarily affect the increase in stock returns obtained by investors who do (Mogonta and Pandowo 2016). This study is not in line with the (Saragih, 2018) which states that the ROE empirically able to provide a positive influence on stock returns.

Effect of EPS on Stock Return. The test results show the panel data regression analysis of the results of t-test for independent variables while EPS amounted to $1.713865 \mathrm{t}$-table value is equal to 1.66691 , which means that the value $t$ count bigger than t-table $(1.713865>1,66$ 691 ), and when viewed from the probability is equal to 0.1028 which is greater than 0.05 $(0.1028>0.05) \mathrm{H}_{0}$ is accepted. This means that Earning per Share has no significant effect on stock returns.

The results of this study are not in accordance with the stakeholder theory states that the company must provide benefits to stakeholders. This is due to the company's ability to use its assets less effective so that the profit generated is very low. The smaller the EPS then the possibility of profits distributed to investors will be small anyway.

These results are consistent with the results of previous studies found that the EPS had no significant effect on stock returns, which means increasing the value of EPS did not increase stock returns obtained by the investor (Maryyam, 2016). This study is not in line with the (Jazai et al., 2019), (Atidhira and Yustina, 2017) and (Kai et al., 2018) which proves that EPS was not able to give effect to stock return.

DER influence on Stock Return. The test results show the panel data regression analysis of the results of t-test for independent variables DER is equal to 0.272026 while the $t$-table value is equal to 1.66691 , which means that the value $t$ count bigger than t-table $(0.272026>$ 1,66691 ), and when viewed from the probability is equal to 0.1028 which is greater than $0.05(0.7885>0.05) \mathrm{H} 0$ is accepted. This means that the Debt to Equity Ratio no significant effect on stock returns.

The results of this study are not by the stakeholder theory states that the company must provide benefits to stakeholders. The company would need additional capital to improve its business so that extra funds are met by a third party. The amount of debt a form of responsibility to make the company set a target to obtain greater profits, with conditions like this then the profits will be used for the personal benefit of the company.

These results are consistent with the results of previous studies found that the DER has no significant effect on stock returns, which means increasing the value of DER does not increase stock returns obtained by the investor (Saragih, 2018).

Influence of CSR to Stock Return. The test results show the panel data regression analysis of the results of t-test for independent variables is equal to -3.095203 CSR, while the t-table value is equal to 1.66691 , which means that the $\mathrm{t}$-count value is smaller than t-table ($3.095203<1,66691)$, and when viewed from the probability is equal to 0.0049 which is less than $0.05(0.0060<0.05) \mathrm{H} 0$ is rejected. This means that CSR has a significant effect on the stock return of manufacturing companies.

The results are consistent with the stakeholder theory states that the company must provide benefits to stakeholders. CSR is a company's commitment to improving the wellbeing through social and environmental responsibility. CSR can be used as one of the 
information to determine the investment decisions by investors as reflected in stock returns are accepted. Companies that undertake CSR activities get long-term benefits by increasing corporate reputation and branding, efficiency, internal party appreciation, and strong profitability.

These results are consistent with results of previous studies found that CSR has a positive effect on stock returns, which means increased disclosure of CSR will lead to increased stock returns obtained by investors conducted. This study is not in line with Bagaskhara (2016), which prove that CSR is not able to give effect to stock return.

Interpretation Model. Interpretation models created includes two things: the number of regression coefficients and the sign to show direction unidirectional relationship (positive) or counterclockwise (negative). Models created in this study formed a panel data regression equation as follows:

$$
\begin{array}{r}
\mathrm{RT}=2.599+4.741 * \mathrm{ROI}-\mathrm{ROE}+0.766 * 0.006 * 0.414 * \mathrm{EPS}+\mathrm{DER} \\
-41.560 * \mathrm{CSR}+\mathrm{e}
\end{array}
$$

Where

$\begin{array}{ll}\text { RT } & \text { : Return Saham } \\ \text { ROI } & \text { : Return on Investment } \\ \text { ROE } & \text { : Return on Equity } \\ \text { EPS } & \text { : Earning per Share } \\ \text { DER } & \text { : Debt to Equity Ratio } \\ \text { CSR } & : \text { Corporate Social Responsibility } \\ \text { Intercept } & : 2,599 \\ \text { e } & : \text { Error term }\end{array}$

\section{DISCUSSION}

Influence ROI on Stock Return. The test results show the panel data regression analysis of the results of t-test for independent variables ROI is equal to 0.290988 while the value of the t-table with $\propto=5 \%$ and $\mathrm{df}=(\mathrm{nk}), \mathrm{df}=(76-5)=71$ where $\mathrm{t}$-table is equal to 1.66691, which means that the value $t$ count is smaller than $\mathrm{t}$-table $(0.290988<1.66691)$, and when viewed from the probability is equal to 0.7742 which is greater than $0.05(0.7742>0.05)$ $\mathrm{HO}$ is accepted. This means that the return on investment has no significant effect.

The results of this study are not in accordance with the stakeholder theory states that the company must provide benefits to stakeholders. One measure of financial profitability ratios to determine the ROI of corporate profits is, the higher the level of profit generated then raise the company's stock price. However, when the company gets additional profit, the company tends to act to maximize the benefit of the company (private interests) so that the welfare of shareholders less than the maximum. The rate of return earned is not affected by the high ROI that is caused by the internal transfer of profits for the sake of the company.

These results are consistent with the results of previous studies found that ROI has no significant effect on stock returns, which means increasing the ROI is not necessarily impact to rising stock returns obtained by investors conducted by (Sari et al., 2017). This study is not in line with the (Jazai et al., 2019) which states that the ROI affects stock returns. 
ROE influence on Stock Return. The test results show the panel data regression analysis of the results of t-test for independent variables ROE is equal to -0.162782 while t-table value is equal to 1.66691 , which means that the t-count value is smaller than t-table ($0.162782<1.66691)$, and when viewed from the probability is equal to 0.8724 which is greater than $0.05(0.8724>0.05) \mathrm{H} 0$ is accepted. This means that the Return on Equity has no significant effect on stock returns.

The results of this study are not in accordance with the stakeholder theory states that the company must provide benefits to stakeholders. ROE is a financial measuring tool to calculate how big the company's profit on own capital that has been managed by the company. The high ROE will increase because stock returns ROE describes the company generated profit. However, the additional profits from the company are used for long-term business expansion, so the returns provided are not allocated to shareholders. Companies tend to be concerned with their own interests by using the return for the continuation of the business so that the welfare of shareholders less preferred.

These results are consistent with results of previous studies found that the ROE does not have a significant effect on stock returns, which means increasing the value of ROE does not necessarily affect the increase in stock returns obtained by investors who do and (Mogonta and Pandowo, 2016), This study is not in line with the Saragih (2018) which states that the ROE empirically able to provide a positive influence on stock returns.

Effect of EPS on Stock Return. The test results show the panel data regression analysis of the results of t-test for independent variables while EPS amounted to $1.713865 \mathrm{t}$-table value is equal to 1.66691 , which means that the value t count bigger than t-table (1.713865> 1, 66 691), and when viewed from the probability is equal to 0.1028 which is greater than 0.05 $(0.1028>0.05) \mathrm{H} 0$ is accepted. This means that Earning per Share has no significant effect on stock returns.

The results of this study are not by the stakeholder theory states that the company must provide benefits to stakeholders. This is due to the company's ability to use its assets less effective so that the profit generated is very low. The smaller the EPS then the possibility of profits distributed to investors will be small anyway.

These results are consistent with results of previous studies found that the EPS had no significant effect on stock returns, which means increasing the value of EPS did not increase stock returns obtained by the investor (Maryyam, 2016). This study is not in line with the (Jazai et al., 2019), (Atidhira and Yustina 2017)and (Kai et al., 2018) which proves that EPS was not able to give effect to stock return.

DER influence on Stock Return. The test results show the panel data regression analysis of the results of t-test for independent variables DER is equal to 0.272026 while the t-table value is equal to 1.66691 , which means that the value $t$ count bigger than $t$-table $(0.272026>$ $1,66691)$, and when viewed from the probability is equal to 0.1028 which is greater than $0.05(0.7885>0.05) \mathrm{H} 0$ is accepted. This means that the Debt to Equity Ratio no significant effect on stock returns.

The results of this study are not by the stakeholder theory states that the company must provide benefits to stakeholders. The company would need additional capital to improve its business so that extra funds are met by a third party. The amount of debt a form of 
responsibility to make the company set a target to obtain greater profits, with conditions like this then the profits will be used for the personal benefit of the company.

These results are consistent with the results of previous studies found that the DER has no significant effect on stock returns, which means increasing the value of DER does not increase stock returns obtained by the investor (Saragih, 2018).

Influence of CSR to Stock Return. The test results show the panel data regression analysis of the results of t-test for independent variables is equal to -3.095203 CSR, while the t-table value is equal to 1.66691 , which means that the t-count value is smaller than t-table ($3.095203<1,66691$ ), and when viewed from the probability is equal to 0.0049 which is less than $0.05(0.0060<0.05) \mathrm{H} 0$ is rejected. This means that CSR has a significant effect on the stock return of manufacturing companies.

The results are consistent with the stakeholder theory states that the company must provide benefits to stakeholders. CSR is a company's commitment to improving the wellbeing through social and environmental responsibility. CSR can be used as one of the information to determine the investment decisions by investors as reflected in stock returns are accepted. Companies that undertake CSR activities get long-term benefits by increasing corporate reputation and branding, efficiency, internal party appreciation, and strong profitability.

These results are consistent with results of previous studies found that CSR has a positive effect on stock returns, which means increased disclosure of CSR will lead to increased stock returns obtained by investors conducted. This study is not in line with (Bagaskhara, 2016), which prove that CSR is not able to give effect to stock return.

\section{CONCLUSION}

That ROI, ROE, EPS and DER have no influence on Stock Returns, but CSR has an influence on Manufacturing companies listed on the Indonesia Stock Exchange for the period 2015-2018. Simultaneously that ROI, ROE, EPS, DER has an influence on Manufacturing companies listed on the Indonesia Stock Exchange for the period 2015-2018

Suggestion. (1) for Investor, we recommend that before deciding to invest in the form of shares in a company, investors should consider various factors that may affect the value of stock returns. Investors should not only consider the company's net profit, but also look at other factors such as return on investment, Return on Equity, Earnings per Share, and Corporate Social Responsibility. Preferably suggested in choosing a company that has a good quality or a company that has a good reputation so it can find a large of a company's ability to generate profits above what is invested. (2) for Issuers, preferably for the company to further improve financial performance and the overall performance of the company every year, to increase the confidence of investors to invest in the company. Improving the performance of the company can be done by managing existing capital for activities that can increase added value for companies and investors to more effectively and efficiently. For a manufacturing company that has a value of ROI, ROE, EPS, CSR, and Return Stocks are still relatively very low and low immediately fix and improve financial performance better to compete with similar companies and be able to compete and dominate investors in capital markets.For Further Research, researchers then used the other internal factors that 
can affect stock return as net profit margin, current ratio, Price to Book Value, Price Earning Ratio and Total Asset Turnover so it can reflect the company's internal conditions. Using the external factors that have the possibility of affecting stock returns such as inflation, interest rates, exchange rates, and economic growth and world oil prices.

\section{REFERENCES}

Aigner, Dennis J. (2016). “Corporate Social Responsibility and Financial Performance.” In Corporate Responsibility: Social Action, Institutions and Governance.

Aisah, Ayu, and Kastawan Mandala. (2016). "Pengaruh Return On Equity, Earning Per Share, Firm Size Dan Operating Cash Flow Terhadap Return Saham.” E-Jurnal Manajemen Universitas Udayana.

Alarussi, Ali Saleh, and Sami Mohammed Alhaderi. (2018). "Factors Affecting Profitability in Malaysia." Journal of Economic Studies 45 (3): 442-58.

Anuar, Hasliyawani, and Othman Chin. (2016). "The Development of Debt to Equity Ratio in Capital Structure Model: A Case of Micro Franchising." Procedia Economics and Finance.

Auld, Graeme, Steven Bernstein, and Benjamin Cashore. (2017). "The New Corporate Social Responsibility.” In Corporate Environmental Responsibility.

Ardiprawiro. (2015). "Dasar Manajemen Keuangan.” In . Universitas Gunadarma.

Atidhira, Agung Tri, and Andi Ina Yustina. (2017). "The Influence of Return on Asset, Debt to Equity Ratio, Earnings per Share, and Company Size on Share Return in Property and Real Estate Companies." JAAF (Journal of Applied Accounting and Finance) 1 (2): $128-46$.

Atikah, Nor, Binti Shafai, Azlan Bin, and Yuvaraj Ganesan. (2018). "Earnings Management, Tax Avoidance and Corporate Social Responsibility: Malaysia Evidence." International Academic Journal of Accounting and Financial Management.

Bagaskhara, Gilang. (2016). "Pengaruh Pengungkapan Corporate Social Responsibility, Kinerja Keuangan, Dan Beta Fundamental Terhadap Return Saham.” Jurnal Akuntansi Bisnis XIV (28): 149-74.

Bhattacherjee, Anol. (2012). Social Science Research: Principles, Methods, and Practices. Textbooks Collection. Vol. 9.

Clementin, Felly Sintinia, and Mawar Patuh Priyadi. (2016). "Pengaruh Keputusan Investasi, Pendanaan, Kebijakan Dividen Dan Profitabilitas Terhadap Nilai Perusahaan." Jurnal Ilmu Dan Riset Akuntansi.

Darmadji, Tjiptono, and Fachrudin. (2012). "Pasar Modal Di Indonesia." In Salemba Empat.

Erica, Denny. (2018). “Analisa Rasio Laporan Keuangan Untuk Menilai Kinerja Perusahaan PT Kino Indonesia Tbk.” Ecodemica.

Fahmi, I. (2014). Manajemen Keuangan Perusahaan Dan Pasar Modal. Mitra Wacana Media.

Faisal, Ahmad, Rande Samben, and Salmah Pattisahusiwa. (2018). "Analisis Kinerja Keuangan." Kinerja 14 (1): 6.

Hery. (2015). Analisis Kinerja Manajemen. PT Gramedia Widiasarana Indonesia. https://doi.org/10.1016/j.biomaterials.2014.05.078.

Jazai, Ridwan, Edi Subiyantoro, and Harmono. (2019). "Pengaruh EPS, ROI Dan EVA 
Terhadap Return Saham Perusahaan Otomotif Di Bursa Efek Indonesia (BEI).” JSHP : Jurnal Sosial Humaniora Dan Pendidikan. https://doi.org/10.32487/jshp.v3i1.539.

Jogiyanto, Hartono. (2016). Teori Portofolio Dan Analisis Investasi (Edisi Sepuluh). Yogyakarta: BPFE.

Kai, Khoo De, Ismail Bin, and Abd Rahman. (2018). "The Impact of Financial Indicators towards Stock Returns of Finance Companies Listed on Bursa Malaysiae." International Journal of Academic Research in Accounting, Finance and Management Sciences 8 (3): 128-40.

Karim, Rashed Al, and Tamima Alam. (2013). "An Evaluation of Financial Performance of Private Commercial Banks in Bangladesh: Ratio Analysis." Journal of Business Studies Quarterly.

Kumar, Pankaj. (2017). "Impact of Earning per Share and Price Earning Ratio on Market of Share: A Study on Auto Sector in India." International Journal of Research Granthaalayah.

Laopodis, Nikiforos T., and Andreas Papastamou. (2016). "Dynamic Interactions Between Stock Markets and the Real Economy: Evidence from Emerging Markets." International Journal of Emerging Markets 11 (4): 715-46.

Lee, Frederic, and Bruce Cronin. 2016. Handbook of Research Methods and Applications in Heterodox Economics. Handbook of Research Methods and Applications in Heterodox Economics. https://doi.org/10.4337/9781782548461.

Mogonta, Kanedia, and Merinda Pandowo. (2016). "Analyzing the Effect of Return on Assets, Return on Equity and Earnings Per Share on Market Share Price: A Study of Lq-45 Mining Companies Listed on Indonesia Stock Exchange." Jurnal Riset Ekonomi, Manajemen, Bisnis Dan Akuntansi 4 (2): 703-13.

Maryyam Anwaar. (2016). "Impact of Firms' Performance on Stock Returns (Evidence from Listed Companies of FTSE-100 Index London, UK).” Aufbereitungs-Technik 30 (11): 678-85.

Om, Hari, and Ms Sonal Goel. (2017). "Analysis of Factors Affecting Stock Price Behaviour: A Study on Listed Companies in Bombay Stock Exchange." Imperial Journal of Interdisciplinary Research.

Pistorius, Thomas. (2017). Heterodox Investment Theory: Stochastic Predictability and Uncertainty. Heterodox Investment Theory: Stochastic Predictability and Uncertainty.

Ramalingegowda, Santhosh, Chuan San Wang, and Yong Yu. (2013). "The Role of Financial Reporting Quality in Mitigating the Constraining Effect of Dividend Policy on Investment Decisions." Accounting Review.

Rezaee, Zabihollah. (2016). "Business Sustainability Research: A Theoretical and Integrated Perspective." Journal of Accounting Literature..

Saragih, Joana L. (2018). "The Effects of Return On Assets (ROA), Return On Equity (ROE), and Debt To Equity Ratio (DER) On Stock Returns in Wholesale and Retail Trade Companies Listed in Indonesia Stock Exchange." International Journal of Sciene and Research Methodology 8 (3): 348-67.

Sari, Tantri Widya, Raden Rustan Hidayat, and Sri Sulasmiyati. 2017. "The Influence of Return on Investment (ROI), Return on Equity (ROE), Earnings Per Share (EPS) and Market Value Added (MVA) on Stock Return (Study on Consumer Goods Industry 
That Listed on Indonesia Stock Exchange for 2011-2015)." Jurnal Administrasi Bisnis 46 (1): 172-80. https://doi.org/10.1002/jssc.201500123.

Sholihah, Irma Mar'atus, Syaparuddin, and Nurhayani. (2017). "Analisis Investasi Sektor Industri Manufaktur, Pengaruhnya Terhadap Pertumbuhan Ekonomi Dan Penyerapan Tenaga Kerja Di Indonesia." Jurnal Paradigma Ekonomika.

Shimizu, Chihiro. (2017). "Microstructure of Asset Prices, Property Income and Discount Rates in the Tokyo Residential Market." International Journal of Housing Markets and Analysis 10 (4): 552-71.

Sutrisno. (2013). "Manajemen Keuangan Teori Konsep Dan Aplikasi." In Manajemen Keuangan Teori Konsep Dan Aplikasi.

Surjandari, Asih Dwi, Dewi Anggraeni, Pratiwi Deby Arlita, and Riris Marintan. 2019. "Analysis of Non-Financial Determinants of Company Value In Manufacturing Companies in Indonesia." Jurnal Akuntansi XXIII (02).

Tjolleng, Amir, and Tohap Manurung. (2013). "Analisis Portofolio Dalam Investasi Saham Pada Pasar Modal." D'CARTESIAN.

Zaroni, Akhmad Nur. (2015). "Globalisasi Ekonomi Dan Implikasinya Bagi Negara-Negara Berkembang : Telaah Pendekatan Ekonomi Islam.” AL-TIJARY. 